\title{
A Case of Congenital Cholesteatoma of the External Auditory Canal Removed Using an Endoscope
}

\author{
Yukari Kano, Hiroaki Shimogori, Kazuma Sugahara, \\ Shunsuke Tarumoto and Hiroshi Yamashita
}

\begin{abstract}
Congenital cholesteatoma of the external auditory canal is a rare disease. We report a 3-year-old male child with congenital cholesteatoma of the left external auditory canal. A white mass existed at 10-12 o'clock of the canal. In computed tomography (CT) of the temporal bone, a low-density lesion was located in contact with the tympanic membrane, but not clearly invaded the middle ear cavity. Treatment consisted of removal using an endoscope. At the 7-month postoperative follow-up there was no evidence of any relapses. We discuss herein the indication of surgery for congenital cholesteatoma of the external auditory canal.
\end{abstract}

Keywords : congenital cholesteatoma, external auditory canal, endoscope

\section{References}

1）日本耳鼻咽喉科学会編：耳鼻咽喉科学用語解説集. 317 頁, 金芳堂，京都，2010.

2）神前英明，福井 潤，清水猛史：真珠腫を伴った先天性外 耳道狭窄の 2 症例. Otol Jpn 20：443, 2010.

3）遠藤周一郎, 森山元大, 水越昭仁, 他 : 先天性外耳道狭窄 に真珠腫を合併した 2 症例。耳鼻臨床 補 124：109, 2009.

4) Choi JH, Woo HY, Yoo YS, et al. : Congetinal primary cholesteatoma of external auditory canal. Am J Otolaryngol 32: 247-
249, 2011.

5）佐藤宏昭，水川敦裕，横山哲也：先天性外耳道真珠腫の 2 例. Otol Jpn 18: 455, 2008 .

6）窪田俊憲，渡辺知緒，伊藤 吏，他：内視鏡下経鼓膜的ア プローチによる先天性真珠腫の治療法. Otol Jpn 22：608, 2012.

7) Kobayashi $\mathrm{T}$ : Removal of congenital cholesteatoma in the middle ear using an endoscopy. Pract Otol (Kyoto) 104: 316-317, 2011.
Department of Otolaryngology, Yamaguchi University Graduate School of Medicine
Corresponding Author Address : Yukari Kano

oday@yamaguchi-u.ac.jp 


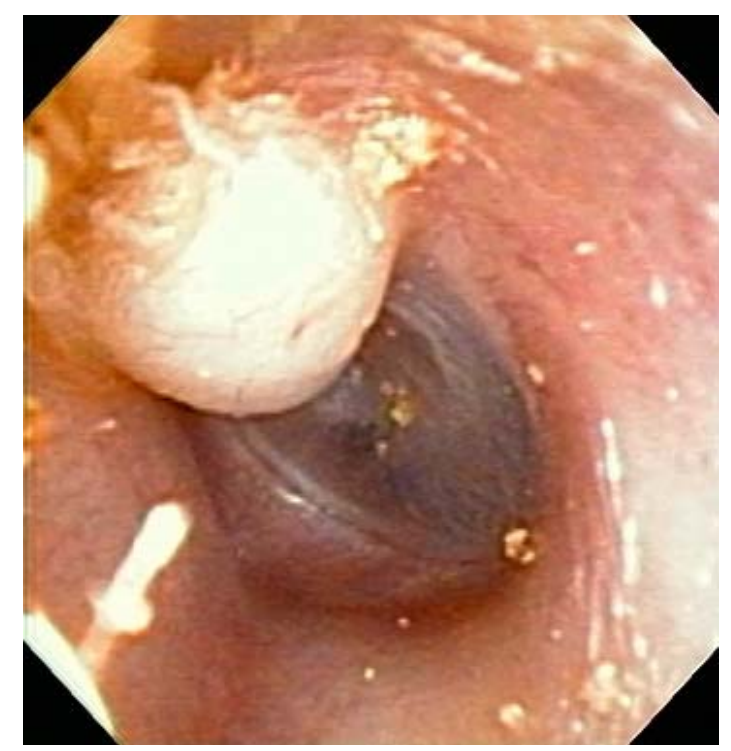

Otoscopic findings (preoperative)

A congenital cholesteatoma of the left external auditory canal is seen.

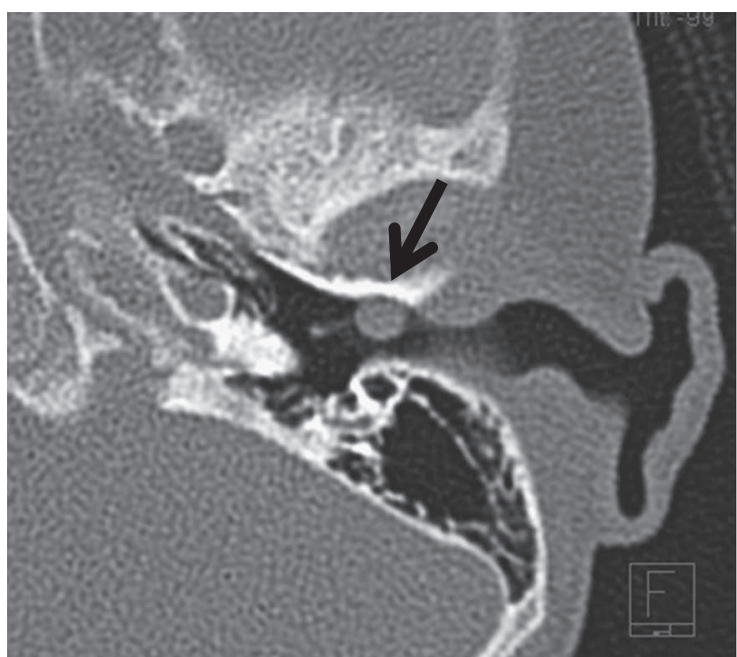

A

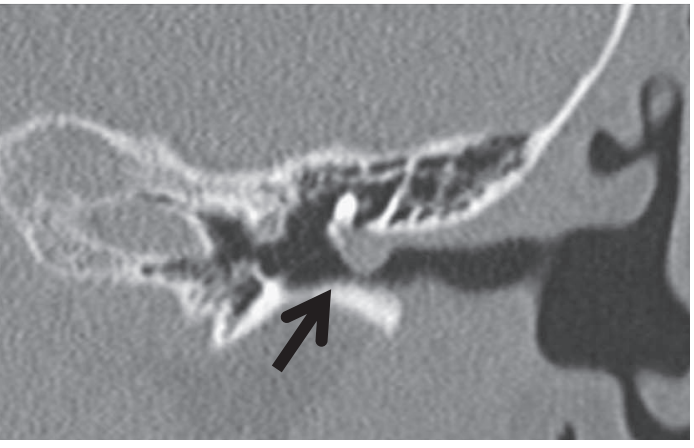

B

CT of the left temporal bone

A low-density lesion is located in contact with the tympanic membrane. 